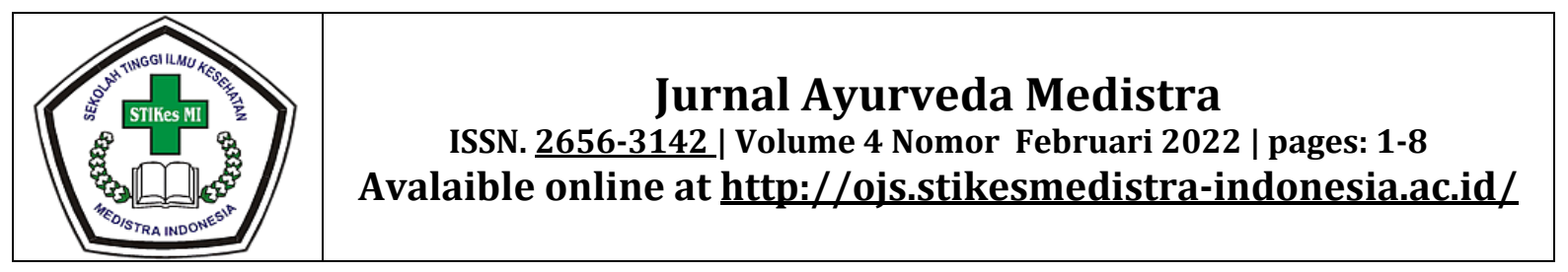

\title{
PERBANDINGAN PREFERENSI MASYARAKAT TERHADAP OBAT TRADISIONAL DAN OBAT SINTETIK DI APOTEK QUALITY KOTA BEKASI TAHUN 2019
}

\author{
Dharma Yanti,S.Pd, M.Farm, Dra. Apt, Nunung Nurhayati, M.Farm \\ Program Studi Farmasi (S1) STIKes Medistra Indonesia, nunung6274@gmail.com, \\ dharmayantilukman@gmail.com 085709252433
}

\begin{abstract}
Abstrak
Obat berdasarkan bahan aktifnya, dibedakan menjadi dua yaitu obat tradisional (berasal dari bahan alam) dan obat sintetik (berasal dari bahan kimia). Penelitian ini bertujuan untuk membandingkan faktor yang mempengaruhi preferensi masyarakat antara memilih obat tradisional dan obat sintetik di Apotek Quality, Jatibening di kota Bekasi.

Desain penelitian ini adalah non-eksperimental observasi dengan pendekatan komparatif. Penelitian dilaksanakan pada bulan Desember 2019 selama 3 minggu di Apotek Quality, Jatibening. Populasi dalam penelitian ini adalah semua orang yang berkunjung dan atau membeli obat di Apotek Quality, Jatibening yang berusia dewasa (>18 tahun). Teknik sampling yang digunakan adalah teknik Insidental Sampling. Pengumpulan data menggunakan wawancara langsung dengan bantuan instrumen kuesioner, datanya kemudian diolah dengan Microsoft Excel.

Hasil penelitian ini menunjukkan bahwa preferensi terhadap obat tradisional $55 \%$ dan terhadap obat sintetik 45\%. Faktor preferensi yang signifikan terhadap obat tradisional adalah faktor ekonomi dan faktor psikologi, sedangkandan obat sintetik di dominasi oleh faktor psikologi, kesimpulan ini diambil dari kuisioner skala likert tentang penggunaan obat tradisional dan obat modern. Kharakteristik responden yang berhubungan dengan preferensi obat di analisa dengan metoda Chi Square adalah : usia, keluhan penyakit,pekerjaan, sumber informasi tentang obat dan status ekonomi. Kharakteristik responden yang tak berkaitan dengan preferensi obat adalah : suku, jenis kelamin, status pernikahan dan tingkat pendidikan
\end{abstract}

Kata kunci: Studi Komparatif, Obat Sintetik, Obat Tradisional

\section{Abstract}

Drugs based on their active ingredients are divided into two, namely traditional drugs (derived from natural ingredients) and synthetic drugs (derived from chemicals). This study aims to compare the factors that influence people's preferences between choosing traditional and synthetic drugs at Apotek Quality, Jatibening in the city of Bekasi.

The design of this research is non-experimental observation with a comparative approach. The research was conducted in Decembre 2019 for 3 weeks at Apotek Quality, Jatibening. The population in this study were all people who visited and or bought drugs at the Quality Pharmacy, Jatibening who were adults (> 18 years). The sampling technique used is the Incidental Sampling technique. Collecting data using direct interviews with the help of a questionnaire instrument, the data is then processed with Microsoft Excel.

The results of this study indicate that the preference for traditional medicine is 55\% and for synthetic medicine is $45 \%$. Significant preference factors for traditional medicine are economic factors and psychological factors, while and synthetic drugs are dominated by psychological factors, this conclusion is drawn from a Likert scale questionnaire about the use of traditional and modern medicines. Characteristics of respondents related to drug preferences analyzed using the Chi Square method are: age, complaints of illness, occupation, sources of information about drugs and economic status. Characteristics of respondents that are not related to drug preference are: ethnicity, gender, marital status and education level

Keyword : Comparative Study, Synthetic Medicine, Traditional Medicine

\section{PENDAHULUAN}

Obat-obatan yang tersedia terdiri dari obat sintetik dan obat tradisional. Obat sintetik adalah obat yang dibuat dari campuran bahan kimia yang tidak dapat disintesis di dalam tubuh. World Health Organisation [1] mendefinisikan obat tradisional sebagai obat asli di suatu negara yang digunakan secara turun-temurun di negara itu atau di negara lain. Obat tradisional harus memenuhi persyaratan antara lain sudah digunakan minimal tiga generasi serta terbukti aman dan bermanfaat. Obat tradisional berupa obat bahan alam dimana obat bahan alam adalah semua obat yang berasal dari bahan alam yang dalam proses pembuatannya belum merupakan isolat murni. Obat bahan alam dapat berupa obat asli, obat tradisional, atau pengembangan dari keduanya [1]

Di Indonesia, terdapat berbagai faktor yang mempengaruhi pemilihan obat. Penentuan pemilihan pengobatan yang dilakukan masyarakat, dipengaruhi oleh beberapa faktor, antara lain seperti pengetahuan, masalah biaya pengobatan, ketidakpuasan terhadap hasil pengobatan, ketidakpuasan dengan pelayanan yang diterima dalam menjalani pengobatan, beberapa kasus malpraktek, dan letak tempat pelayanan kesehatan. Individu melakukan suatu tindakan berdasarkan atas pengalaman, persepsi, pemahaman dan penafsiran atas suatu obyek stimulus atau situasi tertentu. [2].Masyarakat memilih 
pengobatan tradisional disebabkan oleh berbagai faktor seperti pengetahuan dan sikap masyarakat mengenai pengobatan tradisional, pendidikan, pekerjaan, jarak tempat tinggaldengan tempat pengobatan, kebudayaan, kepercayaan dan juga tradisi. [3]

Perkembangan obat tradisional di Jawa Barat mengalami peningkatan hal ini terlihat dimana Provinsi Jawa Barat menduduki urutan pertama (190 industri) dalam Jumlah Industri Obat tradisional di Indonesia yakni sebanyak 92 industri [4]. Menurut Dinas Kesehatan Jawa Barat, data profil pengobatan tradisional di Provinsi Jawa Barat menunjukkan sebanyak 2.629 jumlah pengobat tradisional menggunakan obat tradisional berasaldari tanaman obat yang diramu sendiri maupun obat jadi tradisional Indonesia. Termasuk di dalamnya kota Bekasi sebanyak 739 orang [4].Oleh sebab itulah, peneliti tertarik untuk meneliti preferensi masyarakat terhadap obat tradisional dibandingkan dengan obat modern di Apotek Quality Kelurahan Jatibening, Kecamatan Pondok Gede, Kota Bekasi, Jawa Barat tahun 2019 dan mengetahui karakteristik dan alasan yang mendasari pilihan masyarakat. Kecamatan Pondok Gede dipilih oleh peneliti dikarenakan mempunyai lokasi yangmempunyai letak stratergis yaitu di tengah pusat kota Bekasi yang merupakan pusat perdagangan, perkantoran, dan pemukiman penduduk sehingga pengambilan data dapat lebih mewakili kota Bekasi, Kecamatan Pondok Gede Mempunyai 6 kelurahan, salah satu kelurahan yaitu kelurahan Jatibening merupakan kelurahan terpadat penduduknya dan juga merupakan tempat tinggal peneliti sehingga lebih memudahkan peneliti untuk melakukan penelitian.

\section{METODE PENELITIAN}

Rancangan penelitian ini adalah penelitian kesehatan deskriptif (descriptive) cross-sectional. Pendekatan dilakukan dengan metode penelitian survey (Survey Research Method).

\section{A.WAKTU DAN TEMPAT PENELITIAN}

Penelitian dilaksanakan pada bulan Desember 2019 hingga jumlah sampel terpenuhi di Apotek Quality, JIn Caman Raya kelurahan Jatibening, Kecamatan Pondok Gede, Kota Bekasi.

\section{B.POPULASI DAN SAMPEL}

\section{Populasi Target}

Masyarakat yang bertempat tinggal di kelurahan Jatibening, kecamatan Pondok Gede, kota Bek asi Jawa Barat, yang pernah mengonsumsi obat tradisional dan pernah mengonsumsi obat modern.

\section{Populasi Terjangkau}

Masyarakat yang berkunjung ke Apotek Quality, Jln Caman Raya kelurahan Jatibening, Kecamatan Pondok Gede, Kota Bekasi, Jawa Barat tahun 2019.

\section{Sampel Penelitian}

Sampel yang diambil adalah masyarakat yang memenuhi kriteria inklusisebagai berikut :
a. Masyarakat yang bertempat tinggal di kelurahan Jati Bening
b. Masyarakat yang pernah mengonsumsi obat tradisional.
c. Usia $\geq 18$ tahun.
d. Bersedia ikut dalam penelitian dan menandatangani informed consent.

\section{C.Definisi Variabel Operasional}

Definisi variable operasional yang digunakan dalam penelitian ini bisa dilihat di Tabel.1

\begin{tabular}{|c|c|c|c|c|c|}
\hline No & Variabel & Definisi & Alat Ukur & $\begin{array}{l}\text { Skala } \\
\text { Ukur }\end{array}$ & Hasil Ukur \\
\hline 1 & Usia & $\begin{array}{l}\text { usia responden yang } \\
\text { terhitung sejak tanggal } \\
\text { lahir sampai dengan } \\
\text { waktu penelitian yang } \\
\text { dilakukan }\end{array}$ & Kuesioner & Nominal & $\begin{array}{l}\text { a. Remaja akhir ( } 18-25 \\
\text { tahun) } \\
\text { b. Dewasa ( } 26-45 \text { tahun) } \\
\text { c. Lansia ( } 46-65 \text { tahun) } \\
\text { d. Manula (diatas } 65 \text { tahun) }\end{array}$ \\
\hline 2. & $\begin{array}{l}\text { Jenis } \\
\text { Kelamin }\end{array}$ & $\begin{array}{l}\text { Karateristik seksual } \\
\text { yang dimiliki oleh } \\
\text { responden dan dibagi } \\
\text { menjadi laki-laki dan } \\
\text { perempuan. }\end{array}$ & Kuesioner & Nominal & $\begin{array}{l}\text { a. Laki-laki } \\
\text { b. Perempuan }\end{array}$ \\
\hline 3. & Suku & $\begin{array}{l}\text { Etnik yang melekat } \\
\text { pada seseorang saat } \\
\text { lahir. }\end{array}$ & Kuesioner & Nominal & $\begin{array}{l}\text { a. suku Jawa } \\
\text { b. suku Betawi } \\
\text { c. suku Sunda } \\
\text { d. suku Bengkulu } \\
\text { e. suku Makasar } \\
\text { f. suku Menado } \\
\text { g. suku Melayu } \\
\text { h. suku Minang }\end{array}$ \\
\hline 4. & Pendidikan & $\begin{array}{l}\text { Tingkatan pendidikan } \\
\text { formal terakhir yang } \\
\text { dijalani responden. }\end{array}$ & Kuesioner & Nominal & $\begin{array}{l}\text { a. Dasar/rendah (tidak tamat } \\
\text { SD, SD) } \\
\text { b. Menengah (SMP, SMA) } \\
\text { c. Tinggi (D3, S1, S2, S3) }\end{array}$ \\
\hline 5. & Pekerjaan & $\begin{array}{lr}\text { Profesi atau kegiatan } \\
\text { yang harus dilakukan } \\
\text { seseorang }\end{array}$ & Kuesioner & Nominal & $\begin{array}{l}\text { a. PNS } \\
\text { b. Wiraswasta } \\
\text { c. Pensiunan }\end{array}$ \\
\hline
\end{tabular}




\begin{tabular}{|c|c|c|c|c|c|}
\hline & & $\begin{array}{l}\text { mencari nafkah guna } \\
\text { memenuhi kebutuhan } \\
\text { hidup }\end{array}$ & & & $\begin{array}{l}\text { d. Mahasiswa } \\
\text { e.Profesi Kesehatan } \\
\text { f.Penyedia jasa lainnya }\end{array}$ \\
\hline 6. & Pendapatan & $\begin{array}{l}\text { Jumlah Uang atau gaji } \\
\text { yang diterima dari } \\
\text { pekerjaan seseorang } \\
\text { yang digunakan untuk } \\
\text { memenuhi kebutuhan } \\
\text { hidupnya }\end{array}$ & Kuesioner & Nominal & $\begin{array}{l}\text { a. Rendah } \\
\text { (< Rp. } 1.500 .000 / \text { bulan) } \\
\text { b. Sedang } \\
\text { (Rp.1.500.000- } \\
2.500 .000 / \text { bulan) } \\
\text { c. Tinggi } \\
\text { (Rp. } 2.500 .000- \\
\text { 3.500.000/bulan) } \\
\text { d. Sangat tinggi } \\
\text { (>Rp. } 3.500 .000 / \text { bulan) } \\
\end{array}$ \\
\hline 7. & $\begin{array}{l}\text { Status } \\
\text { Pernikahan }\end{array}$ & $\begin{array}{l}\text { Menggambarkan } \\
\text { hubunganseseorang } \\
\text { dengan lainnya dibagi } \\
\text { menjadi menikah dan } \\
\text { belum menikah. }\end{array}$ & Kuesioner & Nominal & $\begin{array}{l}\text { a. belum menikah } \\
\text { b. sudah menikah }\end{array}$ \\
\hline 8 & Preferensi & $\begin{array}{l}\text { Preferensi konsumen } \\
\text { didefinisikan sebagai } \\
\text { pilihan suka atau tidak } \\
\text { suka seseorang terhadap } \\
\text { suatu produk barang } \\
\text { atau jasa yangdikonsumsi } \\
\text { pada berbagai produk } \\
\text { yang ada (Kotler,2006) }\end{array}$ & Kuesioner & Nominal & $\begin{array}{ll}\text { a. } & \text { obat sintetik } \\
\text { b. } & \text { obat tradisional }\end{array}$ \\
\hline 9 & $\begin{array}{l}\text { Faktor } \\
\text { sosial }\end{array}$ & \begin{tabular}{|lrr} 
Terdiri & dari r faktor \\
informasi & berdasarkan \\
sugesti & orang r lain, \\
teman,keluarga,pengaruh \\
sumber & informasi \\
tersebut. & \\
\end{tabular} & Kuesioner & Ordinal & $\begin{array}{l}\text { STS : sangat tidak setuju } \\
\text { TS: Tidak Setuju } \\
\text { S : Setuju } \\
\text { SS : Sangat Setuju }\end{array}$ \\
\hline 10 & $\begin{array}{l}\text { Faktor } \\
\text { Ekonomi }\end{array}$ & $\begin{array}{l}\text { Terdiri dari faktor biaya, } \\
\text { tenaga dan waktu dalam } \\
\text { proses pengobatan }\end{array}$ & Kuesioner & Ordinal & $\begin{array}{l}\text { STS : Sangat Tidak Setuju } \\
\text { TS : Tidak Setuju } \\
\text { S : Setuju } \\
\text { SS : Sangat Setuju }\end{array}$ \\
\hline 11 & $\begin{array}{l}\text { Faktor } \\
\text { Psikologis }\end{array}$ & $\begin{array}{l}\text { Terdiri dari faktor } \\
\text { motivasi,persepsi, } \\
\text { pengetahuan dan } \\
\text { Kepuasan yang } \\
\text { mendorong masyaraka } \\
\text { untuk menggunakan } \\
\text { pengobatan. }\end{array}$ & Kuesioner & Ordinal & $\begin{array}{l}\text { STS : Sangat Tidak Setuju } \\
\text { TS : : Tidak Setuju } \\
\text { S : Setuju } \\
\text { SS : Sangat Setuju }\end{array}$ \\
\hline 12 & $\begin{array}{l}\text { Faktor } \\
\text { Budaya }\end{array}$ & $\begin{array}{l}\text { Terdiri dari faktor yang } \\
\text { dipengaruhi perilaku } \\
\text { kelompok masyarakat } \\
\text { baik elit maupun } \\
\text { kelompok budaya atau } \\
\text { kebiasaan dan perilaku } \\
\text { konsumen berdasarkan } \\
\text { kelas social, agama, } \\
\text { suku }\end{array}$ & Kuesioner & Ordinal & $\begin{array}{l}\text { STS : Sangat Tidak Setuju } \\
\text { TS: Tidak Setuju } \\
\text { S : Setuju } \\
\text { SS : Sangat Setuju }\end{array}$ \\
\hline
\end{tabular}

\section{Instrumen Penelitian}

Instrumen yang digunakan dalam penelitian ini yaitu kuesioner yang sudah pernah digunakan dalam penelitian yang sudah ada sebelumnya dengan uji validitas dan reliabilitas dengan tingkat signifikansi 0,1 dan nilai alpha cronbach's>0,06.[5]

\section{E. Analisis Data}

Data berupa jawaban dari kuesioner yang diisi konsumen yang menjadi sampel berdasarkan pemilihan obat tradisional dan obat sintetik yang didasarkan pada karateristik umum responden yaitu umur, jenis kelamin, suku, pendidikan, pekerjaan, status pernikahan serta berdasarkan preferensi responden dan dianalisis dengan menggunakan program Microsoft Excel. Analisis data dalam penelitian ini yaitu dengan menggunakan statistik deskriptif dan analisa uji Chi Square.

\section{HASIL ANALISA DAN PEMBAHASAN}

Proses pengambilan data untuk penelitian ini dilakukan selama 3 minggu pada bulan Oktober 2019 di Apotek Quality, Kelurahan Jatibening, di Kota Bekasi. Responden yang terlibat dalam penelitian ini adalah 96 orang. Setiap responden dalam penelitian ini merupakan responden yang memenuhi karakteristik populasi yang ditetapkan.

Berdasarkan data yang telah dikumpulkan, maka hasil penelitian akan dipaparkan pada Tabel.2 di bawah ini :

Tabel .2 Distribusi Frekuensi Responden Berdasarkan Karakterstik Demografis. (N=96)

\begin{tabular}{|l|l|l|l|l|c|c|}
\hline No & \multicolumn{1}{|c|}{ Karakteristik } & \multirow{2}{*}{$\begin{array}{c}\text { Jumlah } \\
\text { Responden }\end{array}$} & & \multicolumn{3}{c|}{ Preferensi } \\
\cline { 4 - 7 } & & & $\begin{array}{c}\text { Obat } \\
\text { Tradisional }\end{array}$ & & Modern \\
\hline 1 & Usia & & & & & \\
\hline & $18-25$ tahun & 5 & 2 & $2 \%$ & 3 & $3 \%$ \\
\hline
\end{tabular}




\begin{tabular}{|c|c|c|c|c|c|c|}
\hline & 26-45 tahun & 33 & 17 & $18 \%$ & 16 & $17 \%$ \\
\hline & 46-65 tahun & 56 & 34 & $35 \%$ & 22 & $23 \%$ \\
\hline & $>65$ tahun & 2 & 0 & $0 \%$ & 2 & $2 \%$ \\
\hline & Total & 96 & 53 & $55 \%$ & 43 & $45 \%$ \\
\hline 2 & Jenis Kelamin & & & & & \\
\hline & Laki laki & 26 & 37 & $38 \%$ & 33 & $34 \%$ \\
\hline & Perempuan & 70 & 16 & $17 \%$ & 10 & $11 \%$ \\
\hline \multirow[t]{4}{*}{3} & Tingkat pendidikan & & & & & \\
\hline & SD & 4 & 3 & $3 \%$ & 1 & $2 \%$ \\
\hline & SMP/SMA & 53 & 29 & $30 \%$ & 25 & $26 \%$ \\
\hline & Perguruan Tinggi/Akademi & 39 & 21 & $22 \%$ & 17 & $18 \%$ \\
\hline \multirow[t]{3}{*}{4} & Status Pernikahan & & & & & \\
\hline & Belum & 5 & 2 & $2 \%$ & 3 & $3 \%$ \\
\hline & Sudah & 91 & 51 & $52 \%$ & 40 & $41 \%$ \\
\hline \multirow{12}{*}{5} & & & & & & \\
\hline & Pekerjaan & & & & & \\
\hline & Ibu rumah tangga & 21 & 14 & $30 \%$ & 7 & $16 \%$ \\
\hline & Pedagang & 19 & 8 & $18 \%$ & 11 & $24 \%$ \\
\hline & Tenaga kesehatan & 8 & 1 & $2 \%$ & 7 & $16 \%$ \\
\hline & Guru & 18 & 14 & $30 \%$ & 4 & $8 \%$ \\
\hline & PNS & 5 & 1 & $2 \%$ & 4 & $8 \%$ \\
\hline & Pensiunan PNS & 5 & 3 & $6 \%$ & 2 & $4 \%$ \\
\hline & Pekerja harian & 1 & 0 & $0 \%$ & 1 & $2 \%$ \\
\hline & Pengusaha & 8 & 7 & $14 \%$ & 1 & $2 \%$ \\
\hline & Karyawan & 6 & 3 & $6 \%$ & 3 & $6 \%$ \\
\hline & Mahasiswa & 5 & 2 & $4 \%$ & 3 & $6 \%$ \\
\hline \multirow[t]{5}{*}{6} & Penghasilan & & & & & \\
\hline & Kurang Dari Rp 1.500.000/Bulan & 8 & 7 & $7 \%$ & 1 & $1 \%$ \\
\hline & Rp1.500.000-2.500.000 & 20 & 5 & $5 \%$ & 15 & $15 \%$ \\
\hline & Rp 2.500.000-3.500.000 & 23 & 15 & $16 \%$ & 8 & $9 \%$ \\
\hline & Lebih dari Rp3.500.000/bulan & 45 & 25 & $26 \%$ & 20 & $21 \%$ \\
\hline \multirow[t]{9}{*}{7} & Suku & & & & & \\
\hline & Jawa & 27 & 15 & $16 \%$ & 12 & $13 \%$ \\
\hline & Betawi & 26 & 15 & $16 \%$ & 11 & $12 \%$ \\
\hline & Sunda & 29 & 16 & $17 \%$ & 13 & $13 \%$ \\
\hline & Manado & 2 & 1 & $1 \%$ & 1 & $1 \%$ \\
\hline & Makasar & 2 & 2 & $2 \%$ & 0 & $0 \%$ \\
\hline & Minang & 8 & 4 & $4 \%$ & 4 & $4 \%$ \\
\hline & Bengkulu & 1 & 0 & & 1 & $1 \%$ \\
\hline & Dayak & 1 & 0 & & 1 & $1 \%$ \\
\hline \multirow[t]{7}{*}{8} & Sumber informasi & & & & & \\
\hline & Media Cetak & 2 & 1 & $2 \%$ & 1 & $2 \%$ \\
\hline & Media Elektronik & 14 & 6 & $12 \%$ & 8 & $18 \%$ \\
\hline & Keluarga/Kerabat & 23 & 21 & $44 \%$ & 2 & $4 \%$ \\
\hline & Teman/Tetangga & 19 & 19 & $40 \%$ & 0 & $0 \%$ \\
\hline & Tenakes & 28 & 1 & $2 \%$ & 27 & $56 \%$ \\
\hline & Seminar & 11 & 5 & $10 \%$ & 6 & $14 \%$ \\
\hline \multirow[t]{26}{*}{9} & Keluhan penyakit & & & & & \\
\hline & Diare & 49 & 23 & $9 \%$ & 26 & $12 \%$ \\
\hline & Darah tinggi & 42 & 19 & $7 \%$ & 23 & $10 \%$ \\
\hline & Batuk & 44 & 27 & $10 \%$ & 17 & $8 \%$ \\
\hline & Mag & 22 & 14 & $5 \%$ & 8 & $4 \%$ \\
\hline & Diabetes & 34 & 14 & $5 \%$ & 20 & $9 \%$ \\
\hline & Anyang anyang & 6 & 6 & $2 \%$ & 0 & $0 \%$ \\
\hline & Flu & 19 & 7 & $3 \%$ & 12 & $5 \%$ \\
\hline & Keseleo/nyeri otot & 14 & 8 & $3 \%$ & 6 & $3 \%$ \\
\hline & Kolesterol & 9 & 4 & $2 \%$ & 5 & $2 \%$ \\
\hline & Stamina & 7 & 2 & $1 \%$ & 5 & $2 \%$ \\
\hline & Nafsu makan & 13 & 11 & $4 \%$ & 2 & $1 \%$ \\
\hline & Rasa sakit/nyeri & 38 & 6 & $2 \%$ & 32 & $15 \%$ \\
\hline & Radang/bengkak & 38 & 18 & $7 \%$ & 20 & $9 \%$ \\
\hline & Alergi & 24 & 9 & $3 \%$ & 15 & $7 \%$ \\
\hline & Sakit perut & 22 & 13 & $5 \%$ & 9 & $4 \%$ \\
\hline & Lancar haid & 10 & 6 & $2 \%$ & 4 & $2 \%$ \\
\hline & Asam urat & 10 & 6 & $2 \%$ & 4 & $2 \%$ \\
\hline & Masukangin/penghangattubuh & 22 & 16 & $6 \%$ & 6 & $3 \%$ \\
\hline & Asma & 2 & 0 & $0 \%$ & 2 & $1 \%$ \\
\hline & Mual & 5 & 0 & $0 \%$ & 5 & $2 \%$ \\
\hline & Mertigo & 5 & 0 & $0 \%$ & 5 & $2 \%$ \\
\hline & Kontrasepsi & 5 & 0 & $0 \%$ & 5 & $2 \%$ \\
\hline & Luka terbuka & 5 & 0 & $0 \%$ & 5 & $2 \%$ \\
\hline & Sakitgigi & 5 & 0 & $0 \%$ & 5 & $2 \%$ \\
\hline & Liver/ hepatitis & 10 & 10 & $4 \%$ & 0 & $0 \%$ \\
\hline
\end{tabular}

Menurut Tabel.2 pada nomor 1 diketahui bahwa dari 96 responden, 53 responden (55\%) memilih obat tradisional dan 43 responden (45\%) memilih obat modern. Sehingga dapat disimpulkan masyarakat lebih 
memilih obat tradisional daripada obat modern.

\section{Hasil Analisa Kharakteristik Terhadap Preferensi Obat}

Keterkaitan kharakteristik responden dengan preferensi obat di uji dengan uji statistik Chi Square.

Faktor dan kharakteristik yang menyebabkan masyarakat yang datang ke apotek Quality lebih menyukai obat tradisional adalah :

Tabel.3 Kharakteristik Responden terhadap Preferensi Obat.

\begin{tabular}{|l|l|l|l|}
\hline No & Kharakteristik & $\begin{array}{l}\text { Adanya Hubungan } \\
\text { dengan Preferensi } \\
\text { Obat }\end{array}$ & $\begin{array}{l}\text { Tidak Ada Hubungan } \\
\text { dengan Preferensi } \\
\text { Obat }\end{array}$ \\
\hline 1 & Jenis Kelamin & & Tidak ada \\
\hline 2 & Status Pernikahan & & Tidak ada \\
\hline 3 & Tingkat Pendidikan & Ada & Tidak ada \\
\hline 4 & Usia & Ada & \\
\hline 5 & Pekerjaan & & Tidak ada \\
\hline 6 & Suku & Ada & \\
\hline 7 & Status Ekonomi & Ada & \\
\hline 8 & Sumber Informasi & Ada & \\
\hline 9 & Keluhan Penyakit & & \\
\hline
\end{tabular}

\section{Hasil Analisa Kuisioner Likert Terhadap Preferensi Obat}

Hasil analisa kuisioner likert terhadap responden yang memilih obat tradisional bisa dilihat di tabel.4

Tabel . 4 Kuisioner Likert dari Responden Obat Tradisional N=53

\begin{tabular}{|c|c|c|c|c|c|c|c|}
\hline \multirow[t]{2}{*}{ NO } & \multirow[b]{2}{*}{ PERNYATAAN } & \multicolumn{4}{|c|}{ FREKUENSI } & \multirow[b]{2}{*}{$\begin{array}{l}\text { RE } \\
\text { RATA }\end{array}$} & \multirow[b]{2}{*}{$\begin{array}{l}\text { KESIMPL } \\
\text { LAN }\end{array}$} \\
\hline & & $\begin{array}{l}\text { STS } \\
(1)\end{array}$ & $\begin{array}{l}\text { TS } \\
(2)\end{array}$ & $\begin{array}{l}\text { S } \\
(3)\end{array}$ & $\begin{array}{l}\text { SS } \\
(4)\end{array}$ & & \\
\hline & FAKTORSOSIAL & & & & & & \\
\hline 1. & $\begin{array}{l}\text { Saya mendapat informasi tentang pengobatan } \\
\text { obat tradisional dari kelompok, keluarga, } \\
\text { saudara dan teman (orang-orang terdekat). }\end{array}$ & 0 & $\begin{array}{r}3 \\
(5,6 \%)\end{array}$ & $\begin{array}{r}45 \\
(84,9 \%)\end{array}$ & $\begin{array}{r}5 \\
(9,4 \%)\end{array}$ & 3,04 & SETUJU \\
\hline 2. & $\begin{array}{l}\text { Saya tertarik untuk mencoba pengobatan obat } \\
\text { tradisional setelahmendengar informasi tersebut. }\end{array}$ & 0 & $\begin{array}{r}10 \\
(18,8 \%)\end{array}$ & $\begin{array}{r}32 \\
(60 \%)\end{array}$ & $\begin{array}{r}11 \\
(20,7 \%)\end{array}$ & 3,02 & SETUJU \\
\hline 3. & $\begin{array}{l}\text { Saya memakai obat Tradisional, karena kelompok, } \\
\text { keluarga,saudara dan teman saya juga memakai obat } \\
\text { tradisional. }\end{array}$ & 0 & $8(15 \%)$ & $\begin{array}{r}20 \\
(37,6 \%)\end{array}$ & $\begin{array}{r}20 \\
(37,6 \%)\end{array}$ & 2,94 & SETUJU \\
\hline & FAKTOR EKONOMI & & & & & & \\
\hline 4 & $\begin{array}{l}\text { Saya menganggap biaya pengobatan obat tradisional } \\
\text { tidak mahal. }\end{array}$ & 0 & $\begin{array}{r}4 \\
(7,5 \%)\end{array}$ & $\begin{array}{r}21 \\
(39,62 \\
\%)\end{array}$ & $\begin{array}{r}28 \\
(52,8 \%)\end{array}$ & 3,45 & $\begin{array}{l}\text { SANGAT } \\
\text { SETUJU }\end{array}$ \\
\hline 5 & $\begin{array}{l}\text { Obat tradisional lebih mudah untuk didapatkan dan } \\
\text { digunakan. }\end{array}$ & 0 & $\begin{array}{r}3 \\
(5,6 \%)\end{array}$ & $\begin{array}{r}21 \\
(39,62 \\
\%)\end{array}$ & $\begin{array}{r}29 \\
(54,7 \%)\end{array}$ & 3,49 & $\begin{array}{l}\text { SANGAT } \\
\text { SETUJU }\end{array}$ \\
\hline 6. & $\begin{array}{l}\text { Waktu pengobatan dengan obat tradisional untuk } \\
\text { kesembuhan penyakit tidak lama. }\end{array}$ & 0 & $\begin{array}{r}13 \\
(23,2 \%) \\
\end{array}$ & $\begin{array}{r}20 \\
(37,6 \%) \\
\end{array}$ & $\begin{array}{r}20 \\
(37,6 \%) \\
\end{array}$ & 3,13 & SETUJU \\
\hline & FAKTOR BUDAYA & & & & & & \\
\hline 7 & $\begin{array}{l}\text { Saya mengonsumsi obat tradisional karena merupakan } \\
\text { warisan budaya, suku, dan bangsa yang saya anut. }\end{array}$ & 0 & $\begin{array}{r}13 \\
(23,2 \%)\end{array}$ & $\begin{array}{r}29 \\
(54,7 \%)\end{array}$ & $\begin{array}{r}11 \\
(20,7 \%)\end{array}$ & 2,96 & SETUJU \\
\hline 8 & $\begin{array}{l}\text { Budaya, suku, atau agama, yang saya anut lebih } \\
\text { menganjurkanpengobatan tradisional dibanding obat } \\
\text { modern. }\end{array}$ & 0 & $3(5,6 \%)$ & $\begin{array}{r}34(64,1 \\
5 \%)\end{array}$ & $\begin{array}{r}16 \\
(30 \%)\end{array}$ & 3,25 & SETUJU \\
\hline 9 & $\begin{array}{l}\text { Budaya, suku, atau agama, yang saya anut memiliki } \\
\text { sudut pandang yang baik terhadap obat tradisional }\end{array}$ & 0 & $\begin{array}{r}2 \\
(3,6 \%) \\
\end{array}$ & $\begin{array}{r}31 \\
(58,5 \%) \\
\end{array}$ & $\begin{array}{r}20 \\
(37,6 \%) \\
\end{array}$ & 3,34 & $\begin{array}{l}\text { SANGAT } \\
\text { SETUJU }\end{array}$ \\
\hline & FAKTOR PSIKOLOGI & & & & & & \\
\hline 10 & $\begin{array}{l}\text { Saya merasakan kepuasan setelah mengonsumsi obat } \\
\text { tradisional. }\end{array}$ & 0 & $1(1,8 \%)$ & $\begin{array}{r}26 \\
(49 \%)\end{array}$ & $\begin{array}{r}26 \\
(49 \%)\end{array}$ & 3,47 & $\begin{array}{l}\text { SANGAT } \\
\text { SETUJU }\end{array}$ \\
\hline 11 & $\begin{array}{l}\text { Saya tahu betul bagaimana manfaat pengobatan } \\
\text { tradisional. }\end{array}$ & 0 & $1(1,8 \%)$ & $\begin{array}{r}31 \\
(58,5 \%)\end{array}$ & $\begin{array}{r}21(39,6 \\
2 \%)\end{array}$ & 3,38 & $\begin{array}{l}\text { SANGAT } \\
\text { SETUJU }\end{array}$ \\
\hline 12 & $\begin{array}{l}\text { Saya menginginkan hal-hal yang sifatnya alami untuk } \\
\text { penyakit } \\
\text { saya. }\end{array}$ & 0 & $\begin{array}{r}2 \\
(3,6 \%)\end{array}$ & $\begin{array}{r}34 \\
(64,15 \\
\%)\end{array}$ & $\begin{array}{r}17 \\
(32 \%)\end{array}$ & 3,28 & $\begin{array}{l}\text { SANGAT } \\
\text { SETUJU }\end{array}$ \\
\hline
\end{tabular}

Menurut Tabel 4. pada butir pernyataan pertama kuisioner faktor sosial $84,9 \%$ responden pemilih obat tradisional menyatakan setuju bahwa mereka mendapat informasi obat tradisional dari teman dan tetangga. Pernyataan ini sesuai dengan data yang diperoleh dari keterkaitan kharakteristik sumber informasi obat dengan preferensi obat pada Tabel. 1 no 8 sumber Informasi pada kolom responden obat tradisional bahwa $42 \%$ pemilih obat tradisonal menyatakan sumber informasi berasal dari kerabat dan $38 \%$ pemilih obat tradisional menyatakan sumber informasi berasal dari teman atau tetangga. Hasil tanggapan responden pada butir 1,2 dan 3 kuisioner faktor sosial keluarga menyatakan setuju bahwa sumber informasi obat mereka adalah teman dan sesuai dengan hasil uji Chi Square: Ada pengaruh terhadap sumber informasi dengan preferensi obat.

Menurut Tabel.4 pada butir pertama kuisioner faktor ekonomi $52 \%$ dari pemilih obat tradisional menyatakan sangat setuju bahwa obat tradisional sangat terjangkau. Dan 54,7\% responden pemilih obat tradisional menyatakan bahwa obat tradisional mudah didapat dan digunakan, oleh karena jelas sekali bahwa faktor ekonomi adalah penentu dari preferensi obat hal ini sesuai dengan hasi uji chi square keterkaitan tingkat pendapatan dengan preferensi obat : ada ketergantungan dari tingkat pendapatan/ekonomi dengan preferensi obat. Hal ini juga terkait dengan hasil uji Chi square keterkaitan pekerjaan dengan preferensi obat yang hasilnya memang ada keterkitan antara pekerjaan dan preferensi obat, dimana responden obat tradisional terbanyak adalah guru $(30 \%)$ dan ibu rumah tangga (30\%) 
Tabel.1.

Tanggapan sebagian besar responden pemilih obat tradisonal menyatakan setuju atau sangat setuju terhadap ketiga butir pernyataan faktor budaya bahwa mengkonsumsi obat tradisional sebagai warisan budaya bangsa, tapi hal ini tidak berkaitan dengan kesukuan. Hasil uji chi square keterkaitan suku dan preferensi obat menyatakan : tidak ada kaitan antara suku dan preferensi obat.

Tanggapan sebagian besar responden pemilih obat tradisonal menyatakan sangat setuju terhadap ketiga butir pernyataan faktor psikologi (26,21 dan 17 responden dari 53 pemilih obat tradisional) setuju $(26,31$ dan 34 dari 53 responden ) dan bahwa mereka merasakan kepuasan mengkonsumsi obat tradisional dan memang menginginkan yang alami untuk menyembuhkan penyakit mereka. Kesimpulan dari kuisioner ini bisa dilihat di Tabel 5 .

Tabel .5 Kesimpulan Kuisioner Likert dari Responden Obat Tradisional

\begin{tabular}{|l|l|l|l|}
\hline No & Faktor & Rata rata & Kesimpulan \\
\hline 1 & Faktor Sosial & 3,00 & SETUJU \\
\hline 2 & Faktor Ekonomi & 3,36 & SANGAT SETUJU \\
\hline 3 & Faktor Budaya & 3,18 & SETUJU \\
\hline 4 & Faktor Psikologi & 3,38 & SANGAT SETUJU \\
\hline
\end{tabular}

Hasil analisa kuisioner likert terhadap responden yang memilih obat modern bisa dilihat di tabel.6

Tabel.6 Kuisioner Likert dari Responden Obat Modern N=43

\begin{tabular}{|c|c|c|c|c|c|c|c|}
\hline \multirow[b]{2}{*}{ NO } & \multirow[b]{2}{*}{ PERNYATAAN } & \multicolumn{4}{|c|}{ FREKUENSI } & \multirow[b]{2}{*}{$\begin{array}{l}\text { RERAT } \\
\text { A }\end{array}$} & \multirow[b]{2}{*}{$\begin{array}{l}\text { KESIMP } \\
\text { ULAN }\end{array}$} \\
\hline & & $\begin{array}{c}\text { STS } \\
(1)\end{array}$ & $\begin{array}{l}\text { TS } \\
(2)\end{array}$ & $\begin{array}{c}\mathrm{S} \\
(3)\end{array}$ & $\begin{array}{l}\text { SS } \\
(4)\end{array}$ & & \\
\hline & FAKTOR SOSIAL & & & & & & \\
\hline 1. & $\begin{array}{l}\text { Saya mendapat informasi tentang terapi obat } \\
\text { modern dari kelompok, keluarga, saudara dan } \\
\text { teman (orang-orang terdekat). }\end{array}$ & $\begin{array}{l}11 \\
(25 \\
6 \%) \\
\end{array}$ & $\begin{array}{l}14 \\
(32,5 \\
\%)\end{array}$ & $\begin{array}{l}18 \\
(42 \%)\end{array}$ & 0 & $\begin{array}{l}2,16279 \\
0698\end{array}$ & $\begin{array}{l}\text { tidak } \\
\text { setuju }\end{array}$ \\
\hline 2. & $\begin{array}{l}\text { Saya berpendapat bahwa mengonsumsi obat } \\
\text { modern lebih bergengsi dan berkelas } \\
\text { dibandingkan obat tradisional. }\end{array}$ & 0 & $\begin{array}{l}9 \\
(21 \%)\end{array}$ & $28(53 \%)$ & $\begin{array}{l}6 \\
(14 \\
\%)\end{array}$ & $\begin{array}{l}2,93023 \\
2558\end{array}$ & Setuju \\
\hline 3. & $\begin{array}{l}\text { Saya memakai obat modern, karena kelompok, } \\
\text { keluarga,saudara dan teman saya juga memakai } \\
\text { obat modern. }\end{array}$ & 0 & $\begin{array}{l}6 \\
(14 \%)\end{array}$ & $22(51 \%)$ & $\begin{array}{l}15 \\
(35 \\
\%)\end{array}$ & $\begin{array}{l}3,20930 \\
2326\end{array}$ & Setuju \\
\hline & FAKTOR EKONOMI & & & & & & \\
\hline 4 & $\begin{array}{l}\text { Saya menganggap biaya pengobatan modern } \\
\text { terjangkau. }\end{array}$ & $\begin{array}{l}1 \\
(2,3 \\
\%)\end{array}$ & $\begin{array}{l}6 \\
(14 \%)\end{array}$ & $\begin{array}{l}27 \\
(62,7 \%)\end{array}$ & $\begin{array}{l}9 \\
(21 \\
\%)\end{array}$ & $\begin{array}{l}3,02325 \\
5814\end{array}$ & Setuju \\
\hline 5 & $\begin{array}{l}\text { Obat modern lebih mudah untuk diperoleh dan } \\
\text { digunakan. }\end{array}$ & 0 & $\begin{array}{l}2 \\
(4,6 \%)\end{array}$ & $24(56 \%)$ & $\begin{array}{l}17 \\
(40 \\
\%)\end{array}$ & $\begin{array}{l}3,34883 \\
7209\end{array}$ & $\begin{array}{l}\text { sangat } \\
\text { setuju }\end{array}$ \\
\hline 6. & $\begin{array}{l}\text { Waktu pengobatan modern untuk kesembuhan } \\
\text { penyakit tidaklama. }\end{array}$ & 0 & $\begin{array}{l}11 \\
(25,5 \\
\%)\end{array}$ & $13(30 \%)$ & $\begin{array}{l}19 \\
\\
(44 \\
\%)\end{array}$ & $\begin{array}{l}3,18604 \\
6512\end{array}$ & Setuju \\
\hline & FAKTOR BUDAYA & & & & & & \\
\hline 7 & $\begin{array}{l}\text { Saya mengonsumsi obat modern karena } \\
\text { merupakan anjuranbudaya yang saya anut. }\end{array}$ & 0 & $\begin{array}{l}11 \\
(25,5 \\
\%)\end{array}$ & $24(56 \%)$ & $\begin{array}{l}8 \\
(19 \\
\%)\end{array}$ & $\begin{array}{l}2,93023 \\
2558\end{array}$ & Setuju \\
\hline 8 & $\begin{array}{l}\text { Terdapat budaya pemikiran pada saya, bahwa } \\
\text { pengobatan modern lebih unggul daripada obat } \\
\text { tradisional. }\end{array}$ & 0 & $\begin{array}{l}4(9,2 \\
\%)\end{array}$ & $26(60 \%)$ & $\begin{array}{l}13(3 \\
0 \%)\end{array}$ & $\begin{array}{l}3,20930 \\
2326\end{array}$ & Setuju \\
\hline 9 & $\begin{array}{l}\text { Budaya, suku, atau agama, yang saya anut } \\
\text { memiliki sudutpandang yang cukup baik } \\
\text { terhadap obat modern. }\end{array}$ & 0 & $3(7 \%)$ & $23(53 \%)$ & $\begin{array}{l}17(4 \\
0 \%)\end{array}$ & $\begin{array}{l}3,32558 \\
1395\end{array}$ & $\begin{array}{l}\text { sangat } \\
\text { setuju }\end{array}$ \\
\hline & FAKTOR PSIKOLOGI & & & & & & \\
\hline 10 & $\begin{array}{l}\text { Saya merasakan kepuasan setelah } \\
\text { mengonsumsi obat modern. }\end{array}$ & 0 & $\begin{array}{l}4(9,2 \\
\%)\end{array}$ & $17(40 \%)$ & $\begin{array}{l}22 \\
(51 \\
\%)\end{array}$ & $\begin{array}{l}3,41860 \\
4651\end{array}$ & $\begin{array}{l}\text { sangat } \\
\text { setuju }\end{array}$ \\
\hline 11 & $\begin{array}{l}\text { Saya tahu betul bagaimana manfaat obat } \\
\text { modern. }\end{array}$ & 0 & 2 & $17(40 \%)$ & $\begin{array}{l}24(5 \\
6 \%)\end{array}$ & $\begin{array}{l}3,51162 \\
7907\end{array}$ & $\begin{array}{l}\text { sangat } \\
\text { setuju }\end{array}$ \\
\hline 12 & $\begin{array}{l}\text { Saya lebih percaya terhadap obat modern } \\
\text { dibandingkan obattradisional dalam mengobati } \\
\text { penyakit. }\end{array}$ & 0 & $\begin{array}{l}2 \\
(4,6 \%)\end{array}$ & $17(40 \%)$ & $\begin{array}{l}24(5 \\
6 \%)\end{array}$ & $\begin{array}{l}3,51162 \\
7907\end{array}$ & $\begin{array}{l}\text { sangat } \\
\text { setuju }\end{array}$ \\
\hline
\end{tabular}

Menurut Tabel.6 pada butir pernyataan pertama kuisioner faktor sosial 32\% pemilih obat modern menyatakan sangat tidak setuju dan $25,5 \%$ tidak setuju bahwa mereka mendapat informasi obat modern dari teman dan keluarga. Pernyataan ini sesuai dengan data yang diperoleh dari keterkaitan kharakteristik sumber informasi obat dengan preferensi obat Tabel. 1 bahwa dari $63 \%$ responden pemilih obat moderm menyatakan sumber informasi berasal dari tenaga kesehatan dan $18,6 \%$ responden menyatakan sumber informasi dari media elektronik dan $12 \%$ responden menyatakan sumber informasi dari seminar. Hasil tanggapan responden pada butir 2 dan 3 kuisioner faktor sosial menyatakan setuju bahwa keluarga dan teman mereka menggunakan obat modern. Hasil analisa ini sesuai dengan hasil uji Chi Square : Ada pengaruh terhadap sumber informasi dengan preferensi obat.

Tanggapan $21 \%$ pemilih obat modern pada Tabel .6 menyatakan sangat setuju dan $63 \%$ pemilih obat modern menyatakan bahwa biaya pengobatan dengan obat modern sangat terjangkau. Dan 95\% 
responden (39,5\% sangat setuju dan 56\% menyatakan setuju ) pemilih obat modern menyatakan bahwa obat modern mudah didapat dan digunakan, oleh karena jelas sekali bahwa faktor ekonomi adalah penentu dari preferensi obat hal ini sesuai dengan hasi uji chi square keterkaitan tingkat pendapatan dengan preferensi obat : ada ketergantungan dari tingkat pendapatan/ekonomi dengan preferensi obat.

Tanggapan dari $74,4 \%$ responden ( $44 \%$ menyatakan sangat setuju dan 30,4\% menyatakan setuju ) menyatakan bahwa waktu yang dibutuhkan dari pengobatan modern tidak lama. Hal ini juga terkait dengan hasil uji Chi square keterkaitan pekerjaan dengan preferensi obat yang hasilnya memang ada keterkaitan antara pekerjaan dan preferensi obat, dimana responden obat modern terbanyak adalah pedagang (26\%) dan tenaga kesehatan (16\%) Tabel 1. Dimana profesi pedagang dan tenaga kesehatan sangat menyita waktu.

Tanggapan sebagian besar responden pemilih obat modern menyatakan setuju terhadap ketiga butir pernyataan faktor budaya $(24,26$ dan 23 responden dari 43 pemilih obat modern) bahwa mereka lebih yakin akan manfaat obat modern daripada obat tradisional. Mereka memiliki keyakinan menggunakan obat modern tidak bertentangan dengan agama dan budaya.

Tanggapan sebagian besar responden pemilih obat modern menyatakan sangat setuju terhadap ketiga butir pernyataan faktor psikologi (22,24 dan 24 responden dari 43 pemilih obat modern), dan menyatakan setuju (17,17 dan 17 dari 43 responden ) dan bahwa mereka merasakan kepuasan mengkonsumsi obat modern dan memang menginginkan manfaat obat modern untuk menyembuhkan penyakit mereka. Faktor psikologi yang paling dominan untuk responden ketika obat modern. Kesimpulan dari kuisioner ini bisa dilihat di Tabel.7

Tabel .7 Kesimpulan Kuisioner Likert dari Responden Obat Modern

\begin{tabular}{|l|l|r|l|}
\hline No & Faktor & \multicolumn{1}{|c|}{ Rata rata } & Kesimpulan \\
\hline 1 & Faktor Sosial & 2,76744186 & Setuju \\
\hline 2 & Faktor Ekonomi & 3,186046512 & Setuju \\
\hline 3 & Faktor Budaya & 3,155039 & Setuju \\
\hline 4 & Faktor Psikologi & 3,48062 & sangat setuju \\
\hline
\end{tabular}

Penentuan pemilihan pengobatan yang dilakukan masyarakat, dipengaruhi oleh beberapa faktor, salah satunya adalah masalah biaya pengobatan. Kemudian tingkat sosial ekonomi menggambarkan kedudukan seseorang dalam bermasyarakat yang biasanya ditentukan oleh unsur pendidikan, pekerjaan, dan pendapatan. Tingkat sosial ekonomi dapat mempengaruhi seseorang untuk dapat menentukan suatu pilihan pengobatan yang ada sesuai dengan kemampuannya. Pendapatan dapat digunakan sebagai ukuran kesanggupan seseorang untuk memperoleh pelayanan kesehatan.[6] Selain permasalahan biaya obat, kemudahan dalam memperoleh dan menggunakan obat, serta waktu pengobatan untuk kesembuhan penyakit juga merupakan faktor ekonomi yang cukup penting.Faktor psikologis juga memainkan peran yang penting dalam preferensi. Penentuan pemilihan pengobatan yang dilakukan masyarakatdipengaruhi oleh beberapa faktor psikologis seperti pengetahuan, ketidakpuasan terhadap hasil pengobatan, ketidakpuasan dengan pelayanan yang diterima dalam menjalani pengobatan. [7]

\section{KESIMPULAN DAN SARAN}

\section{KESIMPULAN}

Berdasarkan tujuan dan hasil penelitian, adapun kesimpulan yang dapat peneliti buat adalah sebagai berikut :

1. Sebagian besar responden di Apotek Quality Jatibening di kota Bekasi memiliki preferensi terhadap obat tradisional (55\%) dibandingkan obat modern (45\%) .

2. Sumber informasi obat untuk responden yang memiliki preferensi obat modern kebanyakan berasal dari dokter, perawat, praktisi kesehatan lainnya (63\%), dan media elektronik (19\%). Responden yang memiliki preferensi obat tradisional sumber informasi kebanyakan berasal dari keluarga dan saudara (40\%) dan teman/tetangga (36\%).

3. Faktor yang paling mempengaruhi preferensi responden terhadap obatmodern adalah faktor psikologis.

4. Faktor yang paling mempengaruhi preferensi responden terhadap obattradisional adalah faktor ekonomi, dan psikologi.

5. Keluhan yang paling banyak diobati dengan memakai obat tradisional dan obat modern adalah penyakit diare $(10,6 \%)$. 
6. Kharakteristik responden yang mempengaruhi preferensi obat : usia, jenis pekerjaan, status ekonomi atau tingkat pendapatan, sumber informasi obat dan keluhan penyakit.

7. Kharakteristik responden yang tidak mempengaruhi preferensi obat : jenis kelamin, status pernikahan, tingkat pendidikan dan suku.

\section{SARAN}

Bagi Apotek

Memberikan informasi yang lengkap tentang penggunaan obat sintetik dan obat tradisional serta melakukan penyuluhan bagi masyarakat tentang obat tradisional dan obat sintetik agar dapat menambah pengetahuan masyarakat dalam menentukan pemilihan obat yang tepat.

\section{DAFTAR PUSTAKA}

[1] Aditama, T.Y. 2015, Jamu dan Kesehatan, $2^{\text {th }}$ ed, Lembaga Penerbit Balitbangkes,Jakarta, p. 38.

[2] Ismiyana, F. 2013, 'Gambaran Penggunaan Obat Tradisional Untuk PengobatanSendiri Pada Masyarakat di Desa Jimus Polanharjo Katen', [Online], accessed on 7 November, Available at : Eprints.ums.ac.id/26073/10/NASKAH_PUBLIKASI.pdf

[3] Pangasuti, M. R., 2014, Hubungan Pengetahuan dan Sikap Mengenai Obat Tradisional dan Obat Modern dengan Tindakan Pemilihan Obat unutk Pengobatan Mandiri di Kalangan Masyarakat Desa Bantir, Kecamatan Candiroto, Kabupaten Temanggung, Jawa Tengah , [Online], accessed on 12 July 2017.

[4] Buletin Informasi kefarmasian dan alat kesehatan, $1^{\text {st }}$ edition, 2015, KementrianKesehatan RI, Jakarta Selatan, p. 7.

[5] Yudhianto, Eric., 2017. Perbandingan Preferensi Masyarakat Terhadap Obat Tradisional dan Obat Modern di Puskesmas Sei Agul Kelurahan Karang Berombak Medan tahun 2017. Fakultas Kedokteran Universitas Sumatra Utara, Medan. [Online], accessed 02 Desember 2018, Available at:repository.usu.ac.id/handle/123456789/4821

[6] Matagiwa, P. 2010, Analisis Proses Pengambilan Keputusan Pembelian dan Faktor yang Mempengaruhi Preferensi Konsumen terhadap Obat Paten/Bermerek pada Apotik Wahana - Bekasi, [Online], accessed on 7 November 2017, Available at : Repository.ipb.ac.id/jspui/bitstream/123456789/62680/1/H10pma.pdf

[7] Romadhona, F. F. 2013, 'Hubungan Tingkat Sosial Ekonomi dan PemilihanSumber Pengobatan', Repository Universitas Esa Unggul [Online],accessed 10 July

$$
\text { 2017, Available at : }
$$

http://digilib.esaunggul.ac.id/hubungan-tingkat-sosial-ekonomi- pendidikanpendapatandan-pekerjaan-dan-pemilihan-sumber-pengobatan- rw-06-kelurahan-kemanggisankecamatan-palmerah-jakarta-barat- 1144.html 